ZOOLOGIA 32(5): 345-350, October 2015

http://dx.doi.org/10.1590/S1984-46702015000500003

\title{
Different collecting methods reveal different ecological groups of centipedes (Chilopoda)
}

\author{
Ivan Hadrián Tuf ${ }^{1}$
}

\begin{abstract}
'Department of Ecology and Environmental Sciences, Faculty of Science, Palacký University. Slechtitelu 27, 77900 Olomouc, Czech Republic. E-mail: ivan.tuf@upol.cz
\end{abstract}

\begin{abstract}
Soil invertebrates are studied by a number of methods. Here we used zoological methods (soil sampling, pitfall trapping, litter sifting, and hand collecting) to sample centipede communities in four floodplain forests (Czech Republic, Europe) and compared the efficiency of these methods. Heat-extraction from soil samples was the most effective, followed by pitfall trapping. The centipedes found by us can be divided into five ecological groups: 1) larger, abundant lithobiomorphs, 2) larger, scarcer lithobiomorphs, 3) smaller, soil lithobiomorphs, 4) abundant geophilomorphs, and 5) scarcer geophilomorphs.
\end{abstract}

KEY WORDS. Heat extraction; litter sifting; pitfall trapping; soil sampling.

Soil macrofauna (i.e., soil invertebrates ranging from 2$20 \mathrm{~mm}$ in size) is an important part of terrestrial ecosystems; some soil species are decomposers of dead organic matter, whereas others are predators. Several standard methods have been used for collecting faunistical and coenological data. The easiest and the oldest method is hand collecting using tweezers. Though very adequate for obtaining live animals, this method is time-consuming and difficult to quantify. Another method consists of Barber traps (BARBER 1930), better known as pitfall traps. The latter are widely used in ecological studies for their simplicity, time efficiency and the possibility to leave them in the field for a long time. These traps consist of plastic or glass jars that are embedded deep in the soil and are filled with a solution to preserve the specimens that fall in them (e.g., formaldehyde, ethyleneglycol). Unfortunately, Barber traps mostly catch surface-dwelling species. AdIs (1979) and WooDсоск (2005) concluded the following about pitfall traps: the size of the sample these traps collect is affected by a number of environmental factors (e.g., climate, microclimate, biotope, age of wood, type of soil surface and soil), as well as trap parameters (diameter, shape of mouth, depth, cover, fixation solution, pattern of traps distribution, digging method). They stressed that traps need to be chosen according to the biotope and type of research.

To study animals inhabiting soil (not only the soil surface), it is necessary to sample soil layers. Litter and/or soil sifting is the easiest choice to get soil animal samples (GórNy \& GRÜM 1993). Sifting has the advantage of sampling microsites that are not accessible by other quantitative methods, for example brittle wood, local litter heap etc. Its major disadvantages are that they can damage the invertebrates (e.g., centipedes or diplurans have specific characters on appendages or legs) and are size-selective (the size of the mesh is a compromise between animal size and size of material particles). There are two ways to compare the species's spectrum recorded by individual samples collected by sifting: 1) according to the sampled area and depth of the sifted soil layers (e.g., sifted sample of original size of $25 \mathrm{x}$ $25 \times 5 \mathrm{~cm}$ ); or 2) according to the volume of sifted material (e.g., two litres of sifted material form favourable microsite as decaying stub). The most useful method for quantitative studies is soil sampling. Even though it is a difficult method (due to time and weight aspects), it is the only way to guarantee that all animals from a given surface are sampled, since its success does not depend on the activity of the animals (Zou et al. 2012). After sifting or soil sampling, animals and soil matter need to be separated. There are several methods (e.g., GóRNY \& GRÜM 1993) to do this, which are clustered into two categories: passive and active. Passive methods separate animals and soil particles according to their different physical (shape, size) or chemical (consistency) characteristics. The samples are processed by (i) hand sorting, (ii) sorting by sieve-system (dry or wet sieving, MoRRIs 1922) or (iii) separated in liquids of specific consistency (e.g. Raw 1955). The active methods benefit from the movement of animals in the soil sample. Invertebrates are unearthed by applying (iv) electrical, (v) temperature, (vi) light or (vii) chemical stimuli. The most frequent is the use of positive geotaxis - a decrease in soil humidity and an increase in soil temperature cause the movement of invertebrates to the deepest soil layer. The first thermoextractors were made by BERLESE (1905), and several modifications of it have been designed since (e.g., KEMPSON et al. 1963).

Centipedes are adequate to ascertain the effectiveness of soil macrofauna sampling methods. Generally, they are divided into two large groups that differ in biology. Lithobiomorpha

2015 | Sociedade Brasileira de Zoologia | www.sbzoologia.org.br | www.scielo.br/zool All content of the journal, except where identified, is licensed under a Creative Commons attribution-type BY. 
and Scolopendromorpha centipedes inhabit the soil surface and litter layers. They predate on springtails, potworms, small spiders and harvestmen, and insect larvae. Geophilomorpha, by contrast, are associated with the upper soil layers and hunt small earthworms and potworms, also consuming dead organic matter. In Central Europe, the numbers of species in both groups are similar (TuF \& Tufová 2008). For this reason, different methods of sampling need to be used to estimate species diversity there. Some researchers have described centipede assemblages as epigeic and edaphic in part depending on whether the material was obtained using pitfall traps or soil sampling (e.g., Wytwer 1995, Wytwer \& Tajovský 2009). However, our knowledge about the efficiency of different methods is limited. No important differences have been found among some methods (SMITH et al. 2008) and no significant differences have been detected between the efficiency of pitfall traps and litter sifting (Prasifka et al. 2007). This study aimed to find the best combination of methods to ascertain the centiped species' spectrum in Central European forests.

\section{MATERIAL AND METHODS}

Centipedes were collected by two quantitative (pitfall trapping, soil sampling) and two qualitative (hand collecting, litter sifting) methods. Pitfall traps (PT) were made by using glass jars (0.7 l) with properly fitting plastic cups (0.25 l) filled with $4 \%$ formaldehyde liquid; traps were covered by bark or metal hoods (approximately $2 \mathrm{~cm}$ above surface) and inspected approximately every three weeks. Soil samples (SS) were collected by circle metal probe made from toothed metal tube engraving intact soil samples. Obtained samples (area $1 / 16 \mathrm{~m}^{2}$ and depth $10 \mathrm{~cm}$, leaf litter included) were immediately transported to the laboratory in plastic bags. Litter sifting (LS) was done using sifter with mesh size $5 \mathrm{~mm}$; favourable microsites and microhabitats were selected and sampled. Sifted litter and soil (mainly fermentation layer) material of approximately 31 was transported immediately to the laboratory in plastic bags. Centipedes were hand collected (HC) by using tweezers in favourable microsites such as fallen trunks or branches, under barks, stones and moss cushions, for approximately one hour in each locality, per visit. Soil samples and siftings were successively cultivated in heat-extractors for ten days (60 W bulb, mesh size $5 \mathrm{~mm}$, thickness of material inside funnel up to $10 \mathrm{~cm}$ - TuF \& TVARDík 2005) to total dryness. The material collected by all methods was sorted, identified and stored in the author's private collection in $70 \%$ ethanol. The classification of centipedes into the following categories, relic/ adaptable/eurytopic, is based on their distribution on natural/ antropogenic habitats in the Czech Republic (TuF \& Tufová 2008).

Communities of centipedes from four localities in the Litovelské Pomoraví Protected Landscape Area (PLA), near the city of Olomouc in the Czech Republic, Europe, were sampled. All these localities were situated in hardwood floodplain forests (vegetation association Querco-Ulmetum). The herbal layer included
Anemone nemorosa, Polygonatum spp., Lathyrus vernus, and Maianthenum bifolium. The dominant moss was Eurhynchium hians. The alluvial soil was loamy-sandy to loamy in the localities, with $\mathrm{pH}$ 4.8-5.The annual precipitation was around $520 \mathrm{~mm}$, mean annual temperature was $9.1^{\circ} \mathrm{C}$, the altitude of localities was about 200-230 $\mathrm{m}$ a.s.l. The following four localities were studied: (i) U zámecké Moravy Natural Monument (MOR; 4943'4.256"N, $17^{\circ} 1^{\prime} 57.580^{\prime \prime} \mathrm{E}$, inside Hejtmanka Natural Reserve now), (ii) Vrapač National Nature Reserve (VR1; 4942'40.581”N, 17²'15.038”E), (iii) another site in Vrapač National Nature Reserve (VR2; $49^{\circ} 42^{\prime} 16.703^{\prime \prime} \mathrm{N}, 17^{\circ} 2^{\prime} 33.423^{\prime \prime} \mathrm{E}$ ), (iv) forest mosaic near Horka nad Moravou (HNM; 49 39'12.592”N, 17²1'13.723"E). At MOR, VR1 and VR2, ten pitfall traps were installed during the season from April-September 2001 where four soil samples were taken using litter sifting and hand collecting. Litter sifting as well as hand collecting were applied randomly at the localities in an area of ca one hectare, and all the sifted material was combined into one mixed sample. At VR2 centipedes were collected and evaluated by Tajovský (Pižl, V. \& Tajovský, K. unpubl.) using five traps (from May to September 1997), extraction of five soil samples (May and September 1997) and hand collecting. HNM was sampled by 18 traps (January 1998 to March 2001), 15 soil samples (taken monthly) and by occasional hand collecting. The localities can be divided based on the length of the study (shorter/ longer than one vegetation season): short-term (MOR and VR1) and long-term studied (VR2 and HNM).

\section{RESULTS}

\section{Evaluation of methods}

The combination of all studied methods yielded 11 centipede species at locality MOR; 8 species at locality VR1; 15 species at locality VR2 and 12 species at locality HNM (without litter sieving), respectively (Fig. 1). A comparison between the short-term and long-term sampling has shown that the probability to detect rarer centipedes by any method increases with time. The greatest numbers of species were obtained at all localities by heat extraction of soil samples (more than 60\%). Second came pitfall trapping and litter sifting (Fig. 1).

Beside the species' spectrum sampled by soil samples, 1, 2 or 3 , other species were recorded by pitfall traps exclusively. Lithobius erythrocephalus C.L. Koch, 1847, Lithobius nodulipes Latzel, 1880 and Lithobius piceus L. Koch, 1862 were not present in soil samples and Lithobius forficatus (Linaeus, 1758) was rarely extracted from soil samples (Table 1). Litter sifting was also useful in the short-term; 2 species were collected by this method, at MOR Lithobius agilis C.L. Koch, 1847 and Strigamia transsilvanica (Verhoeff, 1928). In general, litter sifting collected few centipedes (20-55\%, Fig. 1), showing that this method is inefficient; similarly, hand collecting was also ineffective. At three localities (VR1, VR2, HNM) all species were recorded by the combination of soil samples and pitfall traps (Table 1). Other combinations (with litter sifting or hand collection) were not as successful. 
Table 1. Species spectrum recorded by individual methods on studied localities. Methods: (SS) soil sampling, (PT) pitfall trapping, (LS) litter sifting, (HC) hand collecting.

\begin{tabular}{|c|c|c|c|c|c|c|c|c|c|c|c|c|c|c|c|}
\hline & \multicolumn{4}{|c|}{ MOR } & \multicolumn{4}{|c|}{ VR1 } & \multicolumn{4}{|c|}{ VR2 } & \multicolumn{3}{|c|}{ HNM } \\
\hline & SS & PT & LS & $\mathrm{HC}$ & SS & PT & LS & $\mathrm{HC}$ & SS & PT & LS & $\mathrm{HC}$ & SS & PT & $\mathrm{HC}$ \\
\hline Lithobius aeruginosus L. Koch, 1862 & + & - & - & - & - & + & - & - & + & - & - & - & + & - & - \\
\hline Lithobius agilis C.L. Koch, 1847 & - & - & + & - & - & - & - & - & + & + & - & - & + & + & + \\
\hline Lithobius austriacus Verhoeff, 1937 & - & - & - & - & - & - & - & - & + & + & - & - & - & - & - \\
\hline Lithobius curtipes C.L.Koch, 1847 & - & - & - & - & - & - & - & - & + & + & - & - & + & + & + \\
\hline Lithobius erythrocephalus C.L. Koch, 1847 & - & + & - & - & - & - & - & - & - & + & - & - & - & + & + \\
\hline Lithobius forficatus (Linaeus, 1758) & - & + & - & + & + & + & - & - & + & + & - & + & + & + & + \\
\hline Lithobius micropodus (Matic, 1980) & - & - & - & - & + & + & + & - & - & - & - & - & - & - & - \\
\hline Lithobius mutabilis L.Koch, 1862 & + & + & + & + & + & + & + & - & + & + & + & + & + & + & + \\
\hline Lithobius nodulipes Latzel, 1880 & - & - & - & - & - & - & - & - & - & + & - & - & - & - & - \\
\hline Lithobius piceus L. Koch, 1862 & - & - & - & - & - & - & - & - & - & + & - & - & - & - & - \\
\hline Geophilus electricus (Linnaeus, 1758) & + & - & - & - & + & - & - & - & + & - & - & - & - & - & - \\
\hline Geophilus flavus (DeGeer, 1778) & + & - & + & - & + & - & - & - & + & - & - & + & + & + & + \\
\hline Geophilus insculptus Attems, 1895 & - & - & - & - & - & - & - & - & - & - & - & - & + & + & - \\
\hline Geophilus proximus C.L. Koch, 1847 & + & - & - & - & - & - & - & - & + & - & - & - & + & - & - \\
\hline Schendyla nemorensis (C.L. Koch, 1836) & + & - & + & + & + & + & + & - & + & + & + & + & + & + & + \\
\hline Strigamia acuminata (Leach, 1814) & + & - & + & + & + & - & + & - & + & + & + & - & + & + & + \\
\hline Strigamia crassipes (C.L. Koch, 1835) & - & - & - & - & - & - & - & - & + & - & - & - & - & - & - \\
\hline Strigamia transsilvanica (Verhoeff, 1928) & - & - & + & - & - & - & - & - & - & - & - & - & + & + & - \\
\hline Number of species & 7 & 3 & 6 & 4 & 7 & 5 & 4 & - & 12 & 10 & 3 & 4 & 11 & 10 & 8 \\
\hline Number of species together & 11 & & & & 8 & & & & 15 & & & & 12 & & \\
\hline
\end{tabular}

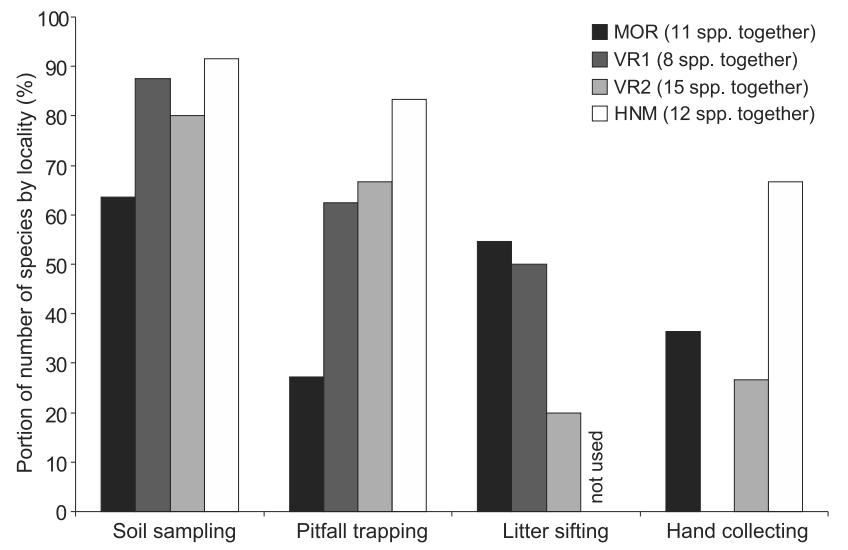

Figure 1. Comparison of relative efficiency of methods for centipede collection. Per cent proportion of species found by individual methods in studied localities.

In summary, the need to use more than one method to uncover the centipede species spectrum was identified (Table 2). All species (18) were only recorded when a combination of pitfall trapping and soil sampling were used; individual methods recorded only 15, 15, 7 and 8 species. Pitfall trapping and heat extraction of soil samples were the only methods capable of recording relic (less abundant) species (Table 3 ).

Table 2. Numbers of species recorded by individual methods and by combinations of two methods.

\begin{tabular}{lcccc}
\hline & $\begin{array}{c}\text { Soil } \\
\text { sampling }\end{array}$ & $\begin{array}{c}\text { Pitfall } \\
\text { trapping }\end{array}$ & $\begin{array}{c}\text { Litter } \\
\text { sifting }\end{array}$ & $\begin{array}{c}\text { Hand } \\
\text { collecting }\end{array}$ \\
\hline Soil sampling & 15 & 18 & 15 & 16 \\
Pitfall trapping & & 15 & 15 & 15 \\
Litter sifting & & & 7 & 10 \\
Hand collecting & & & & 8 \\
\hline
\end{tabular}

\section{Groups of trapped centipedes}

Joint evaluation of the material collected from all four localities in Litovelské Pomoraví PLA has revealed specific patterns of recording species by individual methods (Table 3). Separate groups are characterised according to their preferred environment (soil surface vs. soil layers) and their frequency in samples (abundant vs. less abundant species). Five groups can be recognized, as follow: 1. larger, abundant lithobiomorphs: group of abundant ground-dwelling species of the order Lithobiomorpha with larger body size (more than approximately 
Table 3. Main groups of centipede species according to similar pattern of efficiency of individual methods (number of individuals) in Litovelské Pomoraví PLA. Rarity - ecological valence in Central European conditions (Tuf \& Tufová 2008): (R) relic species, (A) adaptable species, (E) eurytopic species.

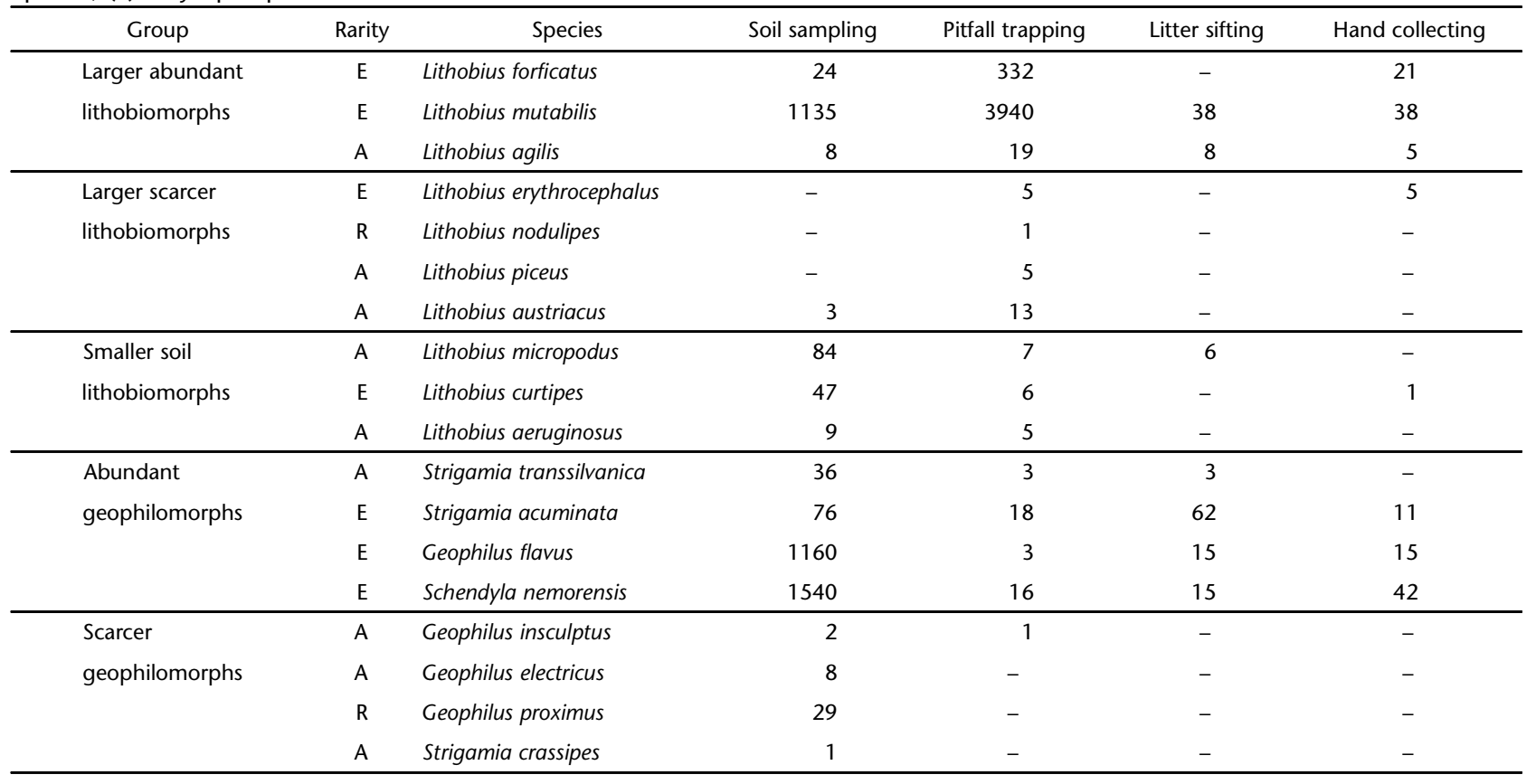

$12 \mathrm{~mm})$. These species were recorded by all methods, but fell more often in pitfall traps. 2. larger, scarcer lithobiomorphs: a group of rare (with low dominances) but large species from the order Lithobiomorpha. These species were recorded by pitfall trapping exclusively; 3. smaller, soil lithobiomorphs: group of centipede species with small body size (less than $12 \mathrm{~mm}$ ) inhabiting cavities and burrows in the soil, offering more favourable conditions (higher humidity, lower temperature fluctuation) and low epigeic activity. These species were recorded mainly by extraction of soil samples and several individuals were collected in pitfall traps; 4 . abundant geophilomorphs: group of centipede species from order Geophilomorpha with abundant populations. These species were extracted from soil samples, and fell in traps also relatively frequently. The probability of recording these species using other methods (sifting, hand collecting) was relatively high as well; 5 . scarcer geophilomorphs: the second group of geophilomorphs, which were relatively rare and were recorded exclusively in soil samples.

\section{DISCUSSION}

\section{Efficiency of methods}

We compared four main methods of soil macrofauna sampling to ascertain how well they determine the local centipede species' spectrum. In our results, the most useful methods were pitfall trapping and extraction of soil samples. Their combination recorded all species in the localities sampled, particularly in the long-term. Litter sifting and hand collecting of centipedes can be complementary methods in short term studies since they collect a large portion of the species' spectrum, but do not efficiently record less abundant species. Similarly to our results, a combination of sifting and hand-collecting were the most effective methods for sampling centipedes in the African savannah with prevailing scolopendromorphs (DruCE et al. 2004).

It is necessary to note that our soil samples were heatextracted by modified Berlese-Tullgren funnels. Soil samples can be processed not only by this Berlese-Tullgren device, but by using Winkler xereclector or to be handsorted. Published comparisons favour Berlese-Tullgren funnels (SMiTH et al. 2008, SABu \& Shiju 2010).

Centipedes are not the only soil animals that are regularly sampled. Terrestrial isopods (Isopoda: Oniscidea) or millipedes (Diplopoda), for example, also have diversified life strategies (Schmalfuss 1984, Hopkin \& Read 1992); some species live exclusively in soil, whereas others are mostly ground-dwelling. Both millipedes and woodlice are among the most important decomposers in terrestrial ecosystems. Thus, to assess their local diversity, a combination of different methods may be necessary. For example, to sample millipedes, a combination of hand collecting and litter sifting are recommended (SNYDER et al. 2006), or hand collecting by an experienced handpicker, including the deeper strata (MEsibov et al. 1995). Similarly, spiders inhabit different strata (litter, soil, trees) and it is useful to 
combine several methods to assess their species diversity (Hövemeyer \& Stippich 2000).

\section{Ecological groups of centipedes}

Centipedes can be divided into five ecological groups according to their probability of being recorded by a particular collecting method. There are two main groups with different biologies - the more surface-dwelling and litter-dwelling lithobiomorphs and the geophilomorphs, which are mainly associated with soil strata (Poser 1990). Lithobiomorphs usually represent a very high proportion of pitfall trap catches (e.g., FrÜND et al. 1997, GRGIČ \& Kos 2009). These two groups can be divided according to their trapability; abundant species are collected by all methods, and less frequent species are recorded only by one method (i.e. by pitfall traps in Lithobiomorpha and soil sampling in Geophilomorpha). The fifth group is composed of small, more endogeic lithobiomorphs - they are caught by pitfall traps and are also extracted from soil samples. These species (and younger specimens of larger lithobiids) live in soil crevices and fissures trying to protect themselves against cannibalism of larger centipedes (RAWCLIFFe 1988) and the drier conditions on the surface.

Since there are several ecological groups of centipedes, a combination of methods is necessary to sample them all. Our results have shown that the most useful methods are pitfall trapping and heat extraction of soil samples. Both methods are relatively inexpensive. Pitfall traps are made from common glass or plastic pots usually and Tullgren apparatuses can be simply created from plastic pails (TuF $\&$ TVARDíK 2005).

\section{ACKNOWLEDGEMENTS}

This paper was partly supported by QJ1230066 grant from the Ministry of Agriculture of the Czech Republic and European project CZ.3.22/1.2.00/12.03445 supported by the Operational Programme Cross Border Co-operation CZ-PL 2007-2013. The author is grateful to two anonymous reviewers which valuable comments and suggestions improved quality of manuscript as well as to A. Dvorska for revising the English of an earlier version of this manuscript.

\section{LITERATURE CITED}

ADIs J (1979) Problems of interpreting arthropod sampling with pitfall traps. Zoologischer Anzeiger 202: 177-184.

BARBER HS (1930) Traps for cave-inhabiting insects. Journal of the Elisha Mitchell Scientific Society 46: 259-265.

Berlese A (1905) Apparecchio par racogliere presto ed gran numero piccoli arthropodi. Redia 2: 85-90.

Druce D, Hamer M, Slotow R (2004) Sampling strategies for millipedes (Diplopoda), centipedes (Chilopoda) and scorpions (Scorpionida) in savanna habitats. African Zoology 39: 293-304.
FrüNd HC, BALKenHol B, RuszKowski B (1997) Chilopoda in forest habitat-islands in north-west Westphalia, Germany. Entomologica Scandinavica 51(Suppl.): 107-114.

Górny M, Grưm L (1993) Methods in Soil Zoology. Amsterdam, Elsevier and PWN, 460p.

GrgIČ T, Kos I (2009) Centipede catch in pitfall traps with leading boards. Acta Biologica Slovenica 52: 107-113.

Hopkin SP, ReAD HJ (1992) The Biology of Millipedes. Oxford, Oxford University Press, 234p.

Hövemeyer K, Stippich G (2000) Assessing spider community structure in a beech forest: Effects of sampling method. European Journal of Entomology 97: 369-375.

Kempson D, Lloyd M, Ghelardi R (1963) A new extractor for woodland litter. Pedobiologia 3: 1-21.

Mesibov R, TAYlor RJ, BRERETON RN (1995) Relative efficiency of pitfall trapping and hand-collecting from plots for sampling of millipedes. Biodiversity \& Conservation 4: 429-439.

MorRis H (1922) On a method of separating insects and other Arthropods from soil. Bulletin of Entomological Research 13: $197-200$.

Poser T (1990) The influence of litter manipulation on the centipedes of a beech wood, p. 235-245. In: Minelu A (Ed.) Proceedings of the 7 th International Congress of Myriapodology. Leiden, E.J. Brill.

Prasifka JR, Lopez MD, Hellmich RL, Lewis LC, Dively GP (2007) Comparison of pitfall traps and litter bags for sampling grounddwelling arthropods. Journal of Applied Entomology 131: 115-120.

RAW F (1955) A flotation extraction process for soil microarthropods, p. 341-346. In: Kevan DKMcE (Ed.) Soil Zoology. London, Butterworths.

RaWCliffe CP (1988) Cannibalism in a lithobiid centipede. Bulletin of the British Myriapod Group 5: 39.

SABU TK, SHIJU RT (2010) Efficacy of pitfall trapping, Winkler and Berlese extraction methods for measuring grounddwelling arthropods in moist-deciduous forests in the Western Ghats. Journal of Insect Science 10: 98. doi: 10.1673/031.010.9801

SCHMALFUSS H (1984) Eco-morphological strategies in terrestrial isopods. Symposia of the Zoological Society of London 53: 49-63.

Smith J, Potts S, Eggleton P (2008) Evaluating the efficiency of sampling methods in assessing soil macrofauna communities in arable systems. European Journal of Soil Biology 44: 271276.

Snyder BA, Draney ML, Sierwald P (2006) Development of an optimal sampling protocol for millipedes (Diplopoda). Journal of Insect Conservation 10: 277-288.

Tuf IH, Tufové J (2008) Proposal of ecological classification of centipede, millipede and terrestrial isopod faunas for evaluation of habitat quality in Czech Republic. Časopis Slezského muzea v Opavě (A) 57: 37-44.

Tuf IH, Tvardík D (2005) Heat-extractor - indispensable tool for soil zoological studies, p. 191-194. In: TAJOVsKÝ K, 
SChlaghamerskí J, PłžL V (Eds.) Contributions to Soil Zoology in Central Europe I. České Budějovice, Institute of Soil Biology, Academy of Science of Czech Republic.

Woodcock BA (2005) Pitfall trapping in ecological studies, p. 37-57. In: Leather SR (Ed.). Insect Sampling in Forest Ecosystems. Oxford, Blackwell Science.

Wytwer J (1995) Faunistical relationships between Chilopoda of forest and urban habitats in Mazowia. Fragmenta Faunistica 38: 87-133.

Submitted: 16 December 2014

Received in revised form: 27 July 2015

Accepted: 11 August 2015

Editorial responsibility: Mauricio O. Moura
WYTwER J, TAjovskÝ K (2009) Changes in centipede assemblages along the vertical and vegetation gradient in Bieszczady Mts. Poland, p. 173-179. In: Tajovský K, Schlaghamerský J, PižL V (Eds.) Contributions to Soil Zoology in Central Europe III. České Budějovice, Institute of Soil Biology, Academy of Science of Czech Republic.

Zou Y, Feng J, Xue D, SAng W, Axmacher JC (2012) A comparison of terrestrial arthropod sampling methods. Journal of Resources and Ecology 3: 174-182. 